\title{
Short-lived climate forcers from current shipping and petroleum activities in the Arctic
}

\author{
K. Ødemark ${ }^{1,3}$, S. B. Dalsøren ${ }^{2}$, B. H. Samset ${ }^{2}$, T. K. Berntsen ${ }^{1,2}$, J. S. Fuglestvedt ${ }^{2}$, and G. Myhre ${ }^{2}$ \\ ${ }^{1}$ University of Oslo, Department of Geosciences, Oslo, Norway \\ ${ }^{2}$ Center for International Climate and Environmental Research - Oslo (CICERO), Oslo, Norway \\ ${ }^{3}$ The Norwegian Meteorological Institute, Oslo, Norway \\ Correspondence to: K. Ødemark (karianne.odemark@met.no)
}

Received: 8 July 2011 - Published in Atmos. Chem. Phys. Discuss.: 29 July 2011

Revised: 20 January 2012 - Accepted: 2 February 2012 - Published: 21 February 2012

\begin{abstract}
Emissions of short-lived climate forcers (SLCF) in the Arctic region are expected to increase, notably from shipping and petroleum extraction. We here discuss changes in atmospheric SLCF concentrations and resulting radiative forcing (RF) from present day shipping and petroleum activities in the Arctic. The three-dimensional chemistry transport OsloCTM2 and a state of the art radiative forcing model are used, based on a coherent dataset of present day Arctic emissions. We find that the net RF of SLCF of shipping in the Arctic region is negative, mainly due to the direct and indirect RF effects of sulphate emissions, while the net RF of SLCF of petroleum extraction is positive, mainly due to the effects of black carbon aerosols in the air and deposited on snow. Strong seasonal variations of the sensitivities to emissions are found. In terms of annual mean values we find that the Arctic sensitivities to SLCF is similar to global average sensitivities. One exception to this is the stronger snow/ice albedo effect from $\mathrm{BC}$ emissions.
\end{abstract}

\section{Introduction}

The Arctic is now experiencing some of the most rapid climate changes on earth: on average, temperature has risen approximately twice the rate of the rest of the world (ACIA, 2005). Repercussions of a warmer Arctic are melting glaciers, reduction in extent and thickness of sea ice, thawing permafrost and rising sea levels (Serreze et al., 2007; Stroeve et al., 2011). Warming also leads to an earlier onset of spring melt, lengthening the melting season. During the 2007 melt season, Arctic sea ice receded to the lowest level observed since satellite measurements began, leading to the first recorded complete opening of the Northwest Pas- sage (NSIDC, 2007). This unlocking of the Arctic ocean will leave it increasingly open to human activity, particularly petroleum production and shipping. The response of the atmosphere and climate to these activities is not well studied.

Petroleum and shipping activities emit a broad mix of gases and aerosols: long-lived greenhouse gases (GHGs), primary particles, such as organic- and black carbon (OC and $\mathrm{BC})$, sulphur dioxide $\left(\mathrm{SO}_{2}\right)$, and the ozone $\left(\mathrm{O}_{3}\right)$ precursors nitrogen oxides $\left(\mathrm{NO}_{\mathrm{x}}\right)$, carbon monoxide $(\mathrm{CO})$ and non-methane hydrocarbons (NMHCs). The emissions affect the chemistry and climate of the atmosphere through several mechanisms: by direct global warming from the GHGs, direct- and indirect effects from aerosols, and by formation of radiatively active $\mathrm{O}_{3}$. These emissions also alters the oxidation capacity of the atmosphere, and will thereby also modify the lifetime of several compounds, including methane, contributing indirectly to radiative forcing (e.g. Isaksen et al., 2009).

The Arctic is a region characterized by high solar angle, high surface albedo, low temperatures and long periods of darkness in the winter and sunlight in summer. These factors result in a different sensitivity to emissions compared to lower latitudes. Haywood and Shine (1997) show that the strongest direct aerosol effect from scattering aerosols occur when the solar zenith angle is $70-80^{\circ}$, despite the decrease in the incident solar radiation as the solar zenith angle increases.

From previous studies, we know that climate impacts of emissions of some short-lived species are strongly dependent on their geographical location. By short-lived components we mean components, or secondary products, that have lifetimes shorter than the longest timescale for mixing in the troposphere, i.e. that is $1-2 \mathrm{yr}$ for interhemispheric mixing. For instance, Fuglestvedt et al. (1999) showed that 
$\mathrm{NO}_{\mathrm{x}}$ emissions in South East Asia caused an $\mathrm{O}_{3} \mathrm{RF}$ up to 8 times higher than the same emission in Europe. Derwent et al. (2001), Wild et al. (2001) and Naik et al. (2005) modelled the indirect forcing (via $\mathrm{O}_{3}$ and $\mathrm{CH}_{4}$ ) from $\mathrm{NO}_{\mathrm{x}}$ emissions and found large dependencies on the region where the emissions occur. Using several CTMs and GCMs, Berntsen et al. (2005) studied the effect of emission changes on concentrations, RF and temperature and found higher chemical and radiative sensitivity to emissions in Asia than for emissions in Europe, while forcings at higher latitudes were more effective in increasing global temperatures (i.e. higher climate sensitivity) due to feed-backs occurring at these high latitudes. Berntsen et al. (2006) compared the effects of identical magnitude emission reductions in different regions and found large differences in the total forcing and temperature change, mainly due to the role of aerosols. Global and Arctic climate is highly sensitive to perturbations in Arctic concentrations of light absorbing particles like BC. BC leads to a decrease in surface albedo when deposited on snow and ice, and can contribute to a shift of the melting season to an earlier onset (Hansen and Nazarenko, 2004; Flanner et al., 2007). This will decrease the albedo in the Arctic, exposing a larger part of the Arctic surface for absorption of solar radiation.

For hygroscopic aerosols the indirect aerosol effect of e.g. sulphate is very dependent on geographical location of emissions (Lauer et al., 2007), this is also the case for the climate response of a given sulfate forcing (Shindell and Faluvegi, 2009). Due to the high sulphur content in marine fuels the impact of sulphur emissions from shipping on climate are potentially large (Corbett et al., 2007; Dalsøren et al., 2009; Eyring et al., 2010; Fuglestvedt et al., 2008).

Granier et al. (2006) studied future potential increases in shipping in the Arctic and found that the summer concentrations of surface ozone may be enhanced by a factor of 2-3, making the $\mathrm{O}_{3}$ levels comparable to those seen in industrialized regions of the Northern Hemisphere.

Recently studies have presented more detailed ship emission inventories including polar routes (Paxian et al., 2010; Corbett et al., 2010; Peters et al., 2011), but few have investigated the effects from these emissions. Here, we use the inventories in Peters et al. (2011) to quantify the impact of current emissions from shipping and petroleum activity in the Arctic, in terms of concentration changes and radiative forcing. A global chemistry-transport model, OsloCTM2, and a radiative transfer model have been used.

\section{Experimental method}

\subsection{Model description}

OsloCTM2 is a global three-dimensional chemistry transport model for the troposphere and stratosphere (Berntsen and Isaksen, 1997; Berglen et al., 2004; Søvde et al., 2008). Here, the OsloCTM2 model was run in T42 resolution $\left(2.8 \times 2.8^{\circ}\right)$ with 60 vertical layers using meteorological data from the Integrated forecast system (IFS) model from the European Centre for Medium-Range Weather Forecasts (ECMWF) for 2006 as explained in mentioned references. A tropospheric version of the model containing 85 chemical species was used. The applied chemistry scheme calculates the evolution of hydrogen, oxygen, nitrogen, and carbon containing gases and also sulphate, primary organic, nitrate and sea salt aerosols. See Myhre et al. (2009) for a description and evaluation of the aerosol module.

Modelled distributions of ozone and ozone precursors were evaluated and compared to observations for ship impacted air in previous studies (Endresen et al., 2003; Dalsøren et al., 2007, 2010). Based on comparisons Dalsøren et al. (2010) suggest increasing ship emissions as an important contributor to increasing background surface ozone in some coastal areas. The black carbon (BC) distribution in the model was compared to measurements and models in Koch et al. (2009), which included a thorough discussion of model performance in the Arctic. Since then the model was updated with a more advanced $\mathrm{BC}$ scheme better reproducing BC measurements at high latitudes (Skeie et al., 2011; Lund and Berntsen, 2011). The revised BC scheme includes seasonal and latitudinal variability in the aging time (conversion from hydrophobic to hydrophilic form) based on detailed simulation with a version of the model that includes the M7 aerosol microphysics module. In the M7 module the conversion from externally mixed BC (freshly emitted hydrophobic particles) to internally mixed $\mathrm{BC}$ particles (coating by sulphate only in M7) is explicitly calculated (Lund and Berntsen, 2011). Based on this study, a simplified version using look-up tables for the aging time was developed (to limit CPU time needed) (Skeie et al., 2011). The effect of the revised $\mathrm{BC}$ scheme used here is particularly pronounced at high latitudes where the production of sulphate is limited during winter by slow oxidation of $\mathrm{SO}_{2}$. This slows down the aging and thus the removal of $\mathrm{BC}$ leading to enhanced wintertime concentrations of $\mathrm{BC}$ in the Arctic in accordance with observations. In each grid cell the budget of $\mathrm{BC}$ in ten snow layers is calculated over the snow season. The scheme includes deposition of BC during snowfall events, dry deposition, melting and sublimation (cf. Rypdal et al., 2009; Skeie et al., 2011 for details). The change in the surface albedo and the implication for radiative forcing of the $\mathrm{BC}$ in the snow is calculated with a radiative a transfer code as described in Stamnes et al. (1988) and Myhre et al. (2009).

For this study the model was run for $1 \mathrm{yr}$, in addition to 3 months spin-up. Several runs are performed; basis simulations without emissions from Arctic ship and petroleum activity, and model runs with these emissions included. By comparing these runs, the contribution from the various emissions was found. 


\subsection{RF calculations}

The RF calculations are performed using a radiative transfer model (Myhre et al., 2009) developed from the DISORT code-base (Stamnes et al., 1988), with four short-wave radiation bands and eight angular multiple scattering streams. The temporal and spatial resolutions are the same as for OsloCTM2.

To calculate the total aerosol RF, we find the difference in top-of-atmosphere shortwave fluxes induced by adding all estimated emissions to a standard background aerosol distribution. We then remove single emission components and run separate calculations to find the individual component forcings. $\mathrm{BC}$ is considered as a combination of external and internally mixed. For more details on size distributions, optical properties, see Myhre et al. (2007). The scheme for calculating RFs from BC deposition on snow (Rypdal et al., 2009 ) is similar to that for the aerosol components. For $\mathrm{O}_{3}$ changes the DISORT code is used for shortwave calculations and a broadband scheme is used for thermal infrared radiation (Myhre et al., 2011). Stratospheric temperature adjustment is included in the RF calculations for $\mathrm{O}_{3}$.

Calculation of the first indirect aerosol effect (cloud albedo effect) is performed through a parameterization of cloud droplet number concentration versus aerosol optical depth, following a method outlined in Quaas et al. (2006) and Quaas and Boucher (2005). We assume a relationship between aerosol mass $\left(m_{\text {aer }}\right)$ and droplet concentration $\left(N_{\mathrm{d}}\right)$ expressed as

$N_{\mathrm{d}}=\exp \left(a_{0}+a_{1} \ln \left(m_{\mathrm{aer}}\right)\right)$

and chose parameters of $a_{0}=4.3, a_{1}=0.3$. The droplet radii are constrained to lie between 2.0 and $25.0 \mu \mathrm{m}$. The indirect aerosol effect is only estimated for water clouds (no mixed phase or ice clouds), nor do we attempt to include other indirect aerosol effects. While recent studies (Penner et al., 2011) have indicated that this type of estimation may underestimate the total aerosol first indirect effect over the industrial era, it is probably better suited to minor perturbations in a clean region as simulated in the present work. Shupe (2011) found that cloud liquid water is most prevalent and most persistent during the warm summer months, but still occurs at least 10$20 \%$ of the time during winter.

\subsection{Emission inventory}

Arctic petroleum and global shipping emissions used in this study are developed by Peters et al. (2011). The gridded set of emissions consists of $\mathrm{NO}_{\mathrm{x}}, \mathrm{CO}, \mathrm{NMVOC}, \mathrm{BC}, \mathrm{OC}$ and $\mathrm{SO}_{2}$ used as input. Long-lived greenhouse gases, $\mathrm{CO}_{2}, \mathrm{CH}_{4}$ and $\mathrm{N}_{2} \mathrm{O}$, are also in the data set, but not used as input in our model here (emission of $\mathrm{CH}_{4}$ is used in simplified RF calculations). The emissions are given in Table 1 and the emission inventory is described in more detail in Peters et al. (2011).
Table 1. Emissions from shipping and petroleum activity in the Arctic in 2004 (values are in kt-NMVOC, kt-SO ${ }_{2}, \mathrm{kt}_{-} \mathrm{NO}_{2}, \mathrm{kt}-\mathrm{CO}$, kt-PM, kt-BC, kt-OC, Mt- $\mathrm{CO}_{2}$, kt- $\mathrm{CH}_{4}$, og t- $\mathrm{N}_{2} \mathrm{O}$. Values are from Peters et al., 2011).

\begin{tabular}{lcc}
\hline Component & Shipping 2004 & Petroleum 2004 \\
\hline $\mathrm{NMVOC}(\mathrm{kt})$ & 21 & 124 \\
$\mathrm{SO}_{2}(\mathrm{kt})$ & 389 & 153 \\
$\mathrm{NO}_{\mathrm{x}}(\mathrm{kt})$ & 679 & 163 \\
$\mathrm{CO}(\mathrm{kt})$ & 65 & 38.4 \\
$\mathrm{PM}(\mathrm{kt})$ & 67 & 46.9 \\
$\mathrm{BC}(\mathrm{kt})$ & 1.6 & 14.7 \\
$\mathrm{OC}(\mathrm{kt})$ & 5.4 & 16 \\
$\mathrm{CO}(\mathrm{Mt})$ & 28 & 82.8 \\
$\mathrm{CH}_{4}(\mathrm{kt})$ & 0.43 & 612 \\
$\mathrm{~N}_{2} \mathrm{O}(\mathrm{t})$ & 686 & 434 \\
\hline
\end{tabular}

Non Arctic petroleum and global emissions from other sectors are taken from the Edgar 3.2 inventory (Olivier et al., 2005). For natural emissions the RETRO data set (Schultz et al., 2007) is used.

From the start of Arctic oil and gas exploration in the 1950s, the production had a rapid growth until the fall of the Soviet Union in 1990. By mid-1990 the production had dropped to $80 \%$ of peak levels. Now the production is back at 1990-levels (Peters et al., 2011). West Russia dominates Arctic petroleum production ( $83 \%$ of cumulative production) followed by Alaska with $15 \%$ (Peters et al., 2011). Around one-half of cumulative production is gas and the remainder oil and condensates.

Tourism, fishing and community re-supply dominate Arctic shipping (Peters et al., 2011 and references therein). Tourism mainly takes place along the coasts of northern Norway, Southwest Greenland and Svalbard. Fishing largely occurs on the ice-free water around Iceland and in the Bering, Barents and Norwegian Seas. Community re-supply is located along the Northern Sea Route (NSR) and the North West Passage. The bulk cargo is dominated by ship traffic along the coast of Norway and around Iceland, followed by export from a few large mining operations in Alaska and Russia. Oil and gas transported from the Arctic by ship is limited and for the most part located on the Eurasian side. The NSR was opened to foreign ships in 1991, and commercial transit traffic, except tourism, has taken place only along this route. After 1993 the traffic has been in steady decline, however 2009 and 2010 saw renewed interest from Western companies to transit the NSR (reducing the journey between Uslan (Korea) and Rotterdam by 4000 nautical miles $-7400 \mathrm{~km}$ ). $9281 \mathrm{Kt}$, or $4.3 \%$ of the global shipping fuel consumption is located within the AMAP (Arctic Monitoring and Assessment Programme) region (for definition of the region, see Peters et al., 2011). 


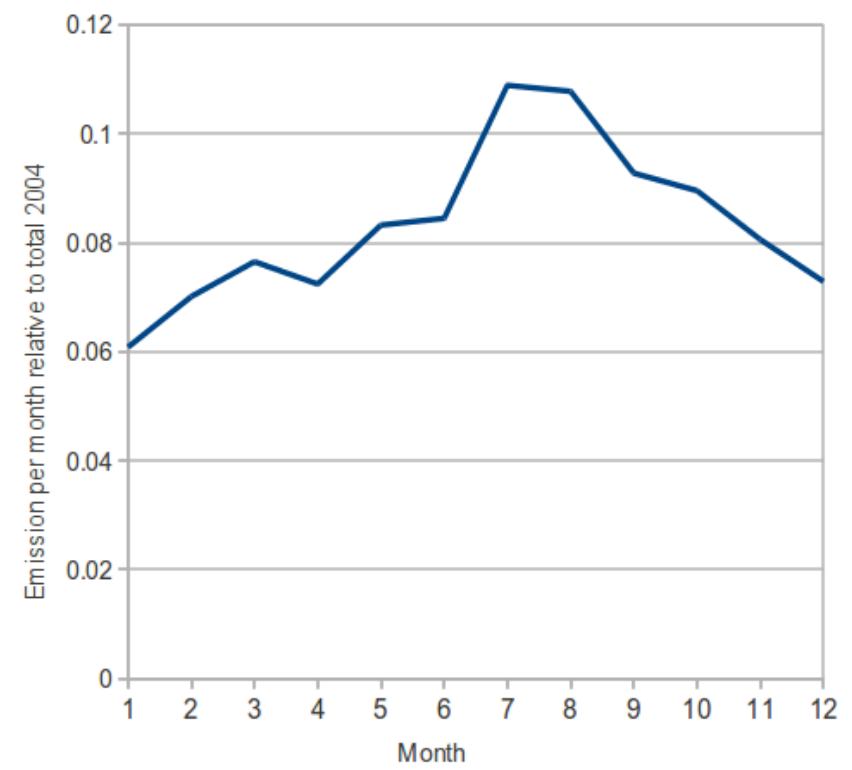

Fig. 1. Shipping emissions within AMAP per month, relative to total shipping emissions within AMAP in 2004.

The seasonal cycle of the shipping emissions can be seen in Fig. 1. In summer, more ships reach further north due to increased open waters, compared to wintertime. This leads to enhanced emissions in summer, with a peak in July. Emissions from petroleum activity are taken to be constant over the year. For more detail on the emissions from Arctic shipping and petroleum activities, see Peters et al. (2011).

Figure 2 shows the annual mean concentration change in $\mathrm{NO}_{\mathrm{x}}$ due to shipping and petroleum activity in the Arctic. Since $\mathrm{NO}_{\mathrm{x}}$ has a relatively short atmospheric lifetime (order of days) the change in concentration from shipping and petroleum emissions is located in the vicinity of the emission source. Thus, the spatial distribution of the emissions is apparent from this figure.

\section{Results}

The impact of emissions related to ship and petroleum activity in the Arctic was found by comparison between a simulation without these emissions in the Arctic and model runs where they were included. For the emissions the AMAP definition was used to set borderline for the Arctic region, for further description see Peters et al. (2011). For the results the borderlines for the Arctic was placed at $60^{\circ} \mathrm{N}$. Below we present the results by component for the two sectors.

\subsection{Tropospheric ozone}

Tropospheric ozone is photochemically produced in the presence of nitrogen oxides $\left(\mathrm{NO}_{\mathrm{x}}=\mathrm{NO}+\mathrm{NO}_{2}\right)$, carbon monoxide $(\mathrm{CO})$ and hydrocarbons. In the pristine Arctic region the production rate of $\mathrm{O}_{3}$ is limited by the amount of $\mathrm{NO}_{\mathrm{x}}$ present. Figure 2 shows the $\mathrm{NO}_{\mathrm{x}}$ increase in the lowest $1.5 \mathrm{~km}$ resulting from Arctic shipping and petroleum activity. The largest enhancement is spatially associated with the locations of oil and gas extraction sites, the largest ports in the Arctic area and in the vicinity of shipping lanes. In these areas Fig. 2 shows concentrations changes up to $0.6 \mathrm{ppb}$.

Seasonal surface ozone change, seasonal tropospheric ozone column and seasonal RF is shown in Figs. 3 and 4, for shipping and petroleum, respectively. Shipping produces the largest surface ozone enhancement with seasonal mean change in summer up to $3 \mathrm{ppb}(12 \%)$ situated along the Norwegian coast, and west coast of Greenland.

Petroleum activity imposes a seasonal mean ozone change of $2 \mathrm{ppb}(5 \%)$ in summer in the vicinity of exploration sites in Alaska and West Russia. Close to the production locations, a negative ozone change of about $-1.5 \mathrm{ppb}(3 \%)$ is found in winter, due to ozone titration. Wintertime titration occurs when $\mathrm{NO}$ reacts with $\mathrm{O}_{3}$. Shipping contributes to an enhancement of $0.4 \mathrm{DU}$ (tropospheric $\mathrm{O}_{3}$ column) in summer, whereas the concentration change is up to $0.25 \mathrm{DU}$ from petroleum activity. The $\mathrm{O}_{3}$ perturbation is largest during summer, for both emission sectors, due to active photochemistry.

The annual direct $\mathrm{RF}$ of $\mathrm{O}_{3}$ from shipping is $4.2 \mathrm{~mW} \mathrm{~m}^{-2}$ in the band $60-90^{\circ} \mathrm{N}$ and from petroleum $1.3 \mathrm{~mW} \mathrm{~m}^{-2}$, also $60-90^{\circ} \mathrm{N}$, see Table 2 (Table 2 also shows global mean RF). The relative difference in forcing is related to the difference in $\mathrm{NO}_{\mathrm{x}}$ emissions from the two sources. Even if there are differences in temporal and spatial distributions of emissions, as well as non-linear chemical effects, the responses are of similar magnitude per unit emission of $\mathrm{NO}_{\mathrm{x}}$.

\subsection{Methane and associated ozone and stratospheric water vapor changes}

Emissions of short-lived components $\left(\mathrm{CO}, \mathrm{NO}_{\mathrm{x}}\right.$ and NMVOCs) influence the chemical loss of methane. Even if methane is not a short-lived climate forcer a significant proportion of the methane perturbation could stem from changes of short-lived components. In this section we have therefore included simplified estimates of methane RF. We used the approach described in Berntsen et al. (2005) and Myhre et al. (2011) to calculate the global RF from methane and associated ozone and stratospheric water vapor changes. The RF values from this method apply from when the perturbations have reached equilibrium conditions.

Due to the relatively high $\mathrm{NO}_{\mathrm{x}} / \mathrm{CO}$ emission ratio both the Arctic shipping and petroleum activity leads to increases in $\mathrm{OH}$ and thereby decreases in methane lifetime (Fuglestvedt et al., 2008). However, the changes in $\mathrm{OH}$ are rather small due to inactive photochemistry in winter. The effect on methane loss is further limited by low temperatures prevailing for most of the year in the Arctic. Due to this it is mainly the ship emissions that have a significant impact on methane 
a)

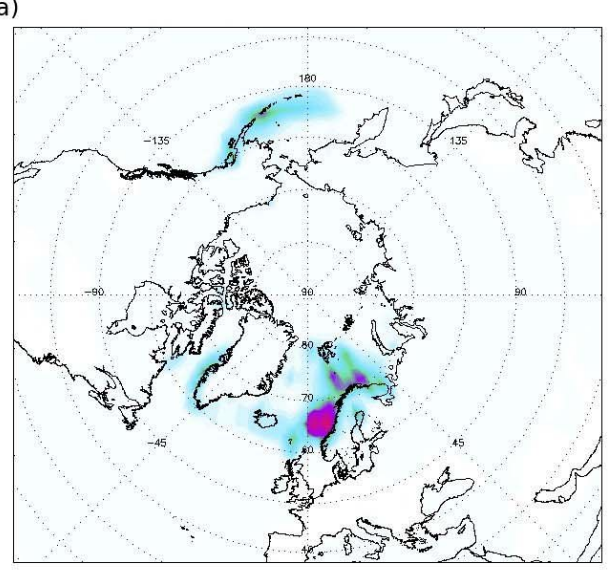

$\begin{array}{llllllll}0.00 & 0.03 & 0.05 & 0.06 & 0.09 & 0.12 & 0.20 & 0.60\end{array}$ b)

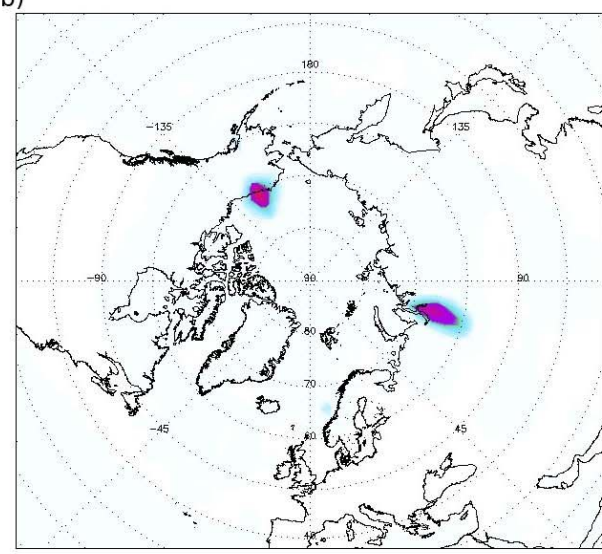

\begin{tabular}{lllllllll}
\hline 0.00 & 0.03 & 0.05 & 0.06 & 0.09 & 0.12 & 0.20 & 0.60
\end{tabular}

Fig. 2. Yearly average contribution to $\mathrm{NO}_{\mathrm{x}}[\mathrm{ppb}]$ in the lowest $1.5 \mathrm{~km}$ of the troposphere from (a) shipping activity and (b) petroleum activity in 2004.
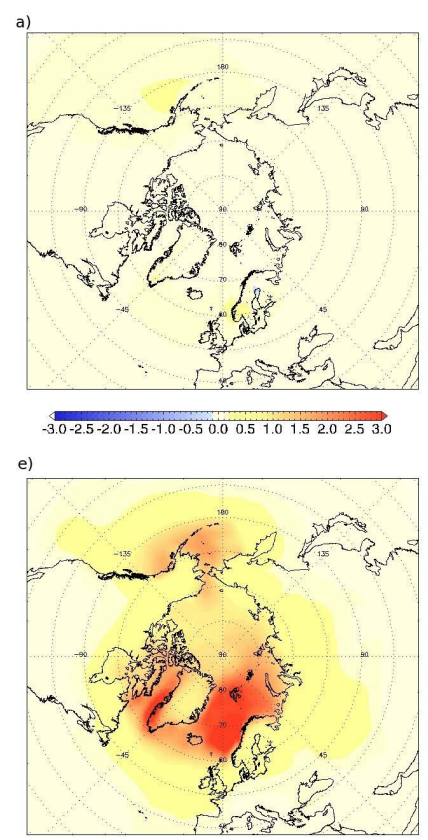

$-3.0-2.5-2.0-1.5-1.0-0.50 .00 .51 .01 .52 .02 .53 .0$
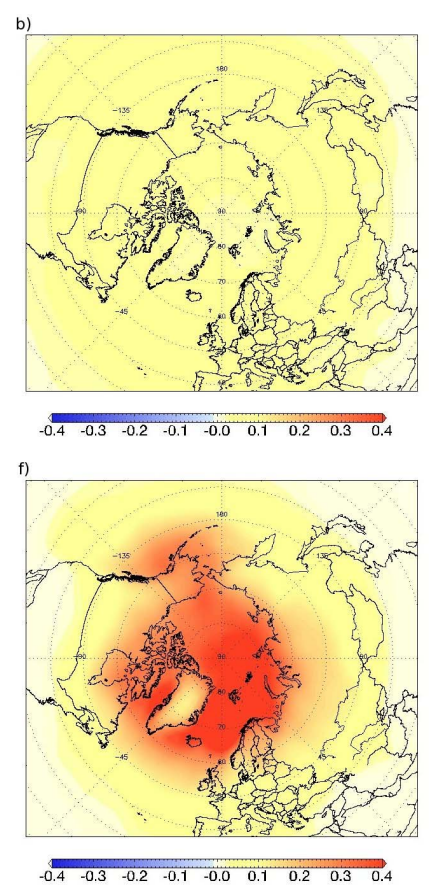
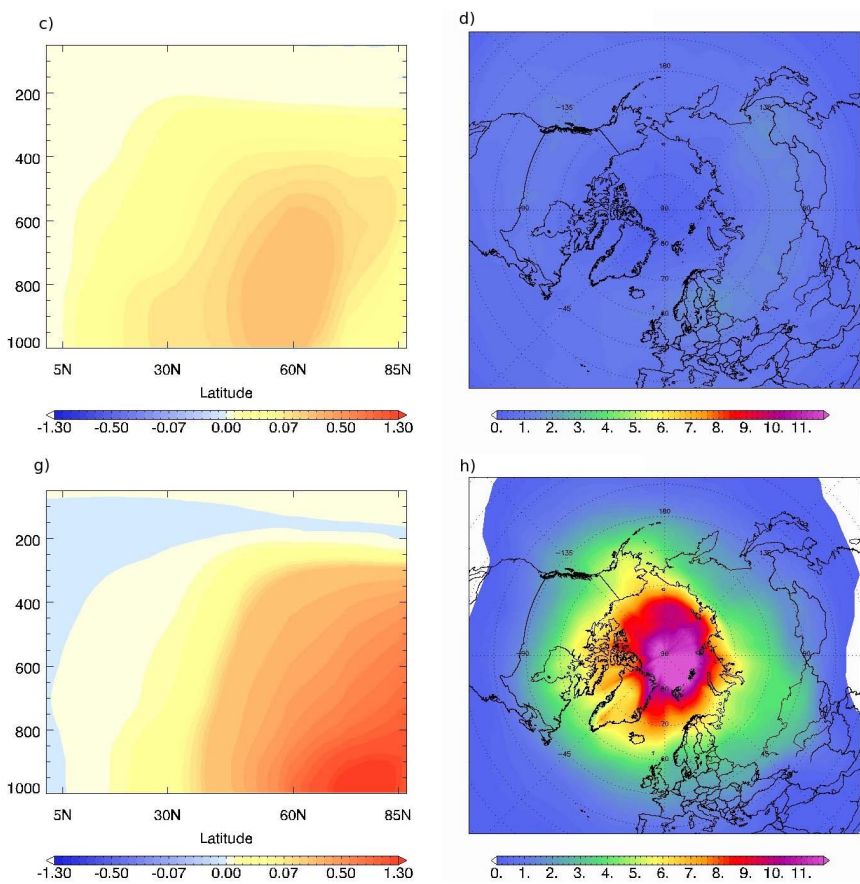
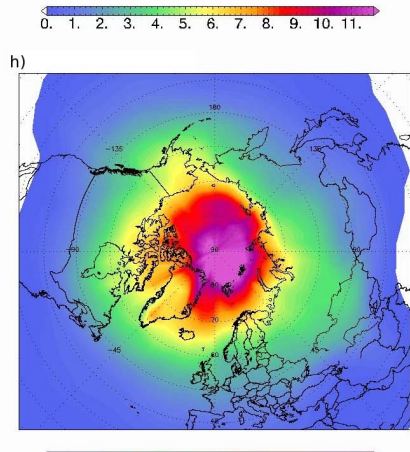

Fig. 3. $\mathrm{O}_{3}$ effects from Arctic shipping emissions. Top panel (a, b, $\mathbf{c}$ and $\left.\mathbf{d}\right)$ are responses from shipping activity in January-February-March, while lower panel (e, $\mathbf{f}, \mathbf{g}$ and $\mathbf{h}$ ) are responses for July-August-September mean. (a and $\mathbf{e})$ Seasonal mean contribution to surface $\mathrm{O}_{3}$ [ppb]. (b and f) Seasonal mean impact on tropospheric $\mathrm{O}_{3}$ column [DU]. (c and $\mathbf{g}$ ) Seasonal zonal mean $\mathrm{O}_{3}$ [ppb]. (d and h) Radiative forcing $\left[\mathrm{mW} \mathrm{m}^{-2}\right]$ due to the ozone changes.

lifetime since the traffic and effect on ozone (Figs. 3 and 4) peak during summer. We find the resulting indirect methane $\mathrm{RF}$ (at steady state, i.e. corresponding to sustained $\mathrm{NO}_{\mathrm{x}}, \mathrm{CO}$ and VOC emissions) from shipping to be $-0.59 \mathrm{~mW} \mathrm{~m}^{-2}$ (global mean). This further results in a methane-induced ozone RF of $-0.18 \mathrm{~mW} \mathrm{~m}^{-2}$ and stratospheric water vapor $\mathrm{RF}$ of $-0.09 \mathrm{~mW} \mathrm{~m}^{-2}$. For the Arctic petroleum activity the forcings due to changes in methane lifetime are very small amounting to $-0.03 \mathrm{~mW} \mathrm{~m}^{-2}$ for methane, $-0.01 \mathrm{~mW} \mathrm{~m}^{-2}$ for ozone and $-0.005 \mathrm{~mW} \mathrm{~m}^{-2}$ for stratospheric $\mathrm{H}_{2} \mathrm{O}$.

The ship emissions of methane (Table 1) are small compared to the total global methane emissions from all anthropogenic and natural sources. We find that the RF due to direct methane emissions from Arctic shipping is negligible. 

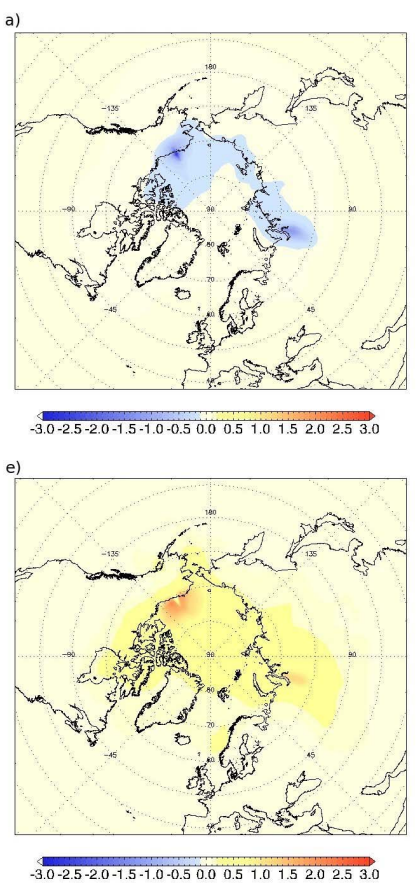
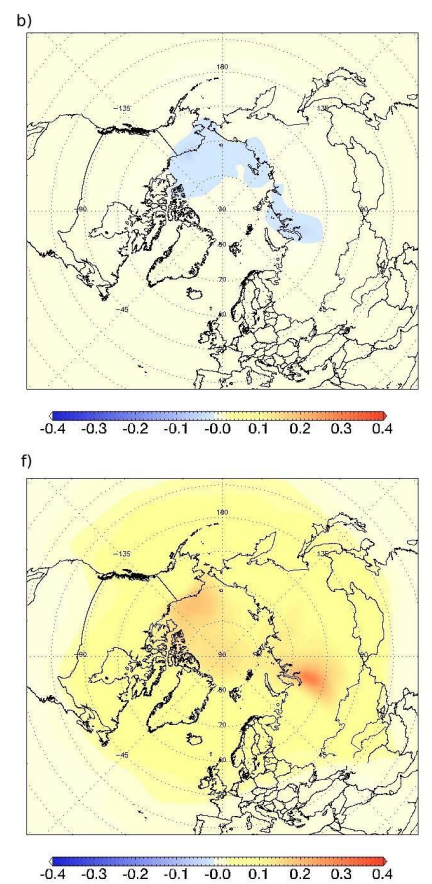
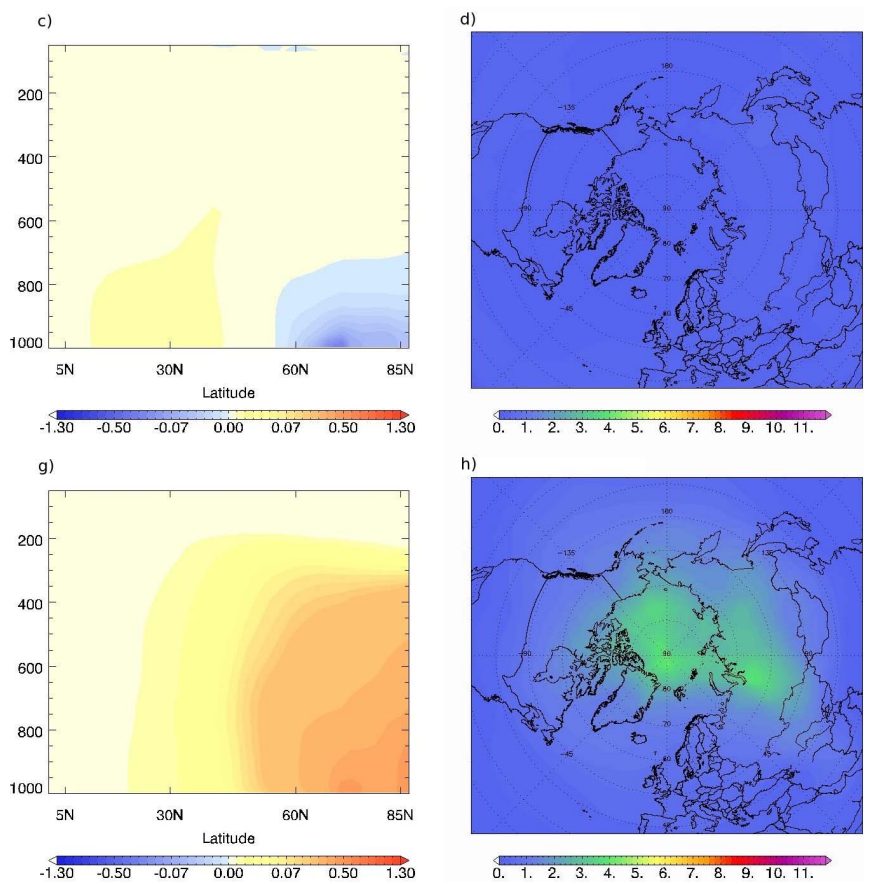

Fig. 4. $\mathrm{O}_{3}$ effects from Arctic petroleum emissions. Top panel (a, b, c and d) are responses from petroleum activity in January-FebruaryMarch, while lower panel (e, f, $\mathbf{g}$ and $\mathbf{h})$ are responses for July-August-September. (a and $\mathbf{e})$ Seasonal mean contribution to surface $\mathrm{O}_{3}$ [ppb]. (b and f) Seasonal mean impact on tropospheric $\mathrm{O}_{3}$ column [DU]. (c and g) Seasonal zonal mean $\mathrm{O}_{3}$ [ppb]. (d and h) Radiative forcing $\left[\mathrm{mW} \mathrm{m}^{-2}\right]$ due to the ozone changes.

Table 2. Global annual mean atmospheric column $\left[\mu \mathrm{g} \mathrm{m}^{-2}\right.$ ] (for $\mathrm{O}_{3}$ : [DU]) and radiative forcing [mW $\left.\mathrm{m}^{-2}\right]$ from ship and petroleum activity in 2004 .

\begin{tabular}{|c|c|c|c|c|c|c|c|c|}
\hline \multirow[b]{3}{*}{ Component } & \multicolumn{4}{|c|}{ Burden $\left(\mu \mathrm{g} \mathrm{m}^{-2}\right)$} & \multicolumn{4}{|c|}{ Radiative Forcing $\left(\mathrm{mW} \mathrm{m}^{-2}\right)$} \\
\hline & \multicolumn{2}{|c|}{ Shipping } & \multicolumn{2}{|c|}{ Petroleum } & \multicolumn{2}{|c|}{ Shipping } & \multicolumn{2}{|c|}{ Petroleum } \\
\hline & Global & $60-90^{\circ}$ & Global & $60-90^{\circ}$ & Global & $60-90^{\circ}$ & Global & $60-90^{\circ}$ \\
\hline Sulphate & 1.4 & 20 & 1.0 & 9.2 & -0.45 & -5.8 & -0.24 & -1.9 \\
\hline Nitrate & 0.30 & 0.75 & 0.003 & -0.024 & -0.06 & -0.13 & -0.0003 & 0.0033 \\
\hline $\mathrm{BC}$ air & 0.04 & 0.38 & 0.48 & 4.1 & 0.08 & 0.60 & 0.86 & 6.5 \\
\hline BC snow & & & & & 0.03 & 0.47 & 1.5 & 20 \\
\hline $\mathrm{OC}$ & 0.17 & 1.4 & 0.49 & 4.6 & -0.02 & -0.13 & -0.06 & -0.42 \\
\hline Aerosol Indirect Effect & & & & & -2.0 & -19 & -0.18 & -2.0 \\
\hline Ozone & 0.026 & 0.17 & 0.008 & 0.046 & 0.57 & 4.2 & 0.23 & 1.3 \\
\hline Methane Indirect & & & & & -0.86 & & -0.045 & \\
\hline
\end{tabular}

The methane emissions from the petroleum activity are more than a factor 1000 larger than for Arctic shipping (Table 1). The resulting change in methane concentration at equilibrium leads to $\mathrm{RF}$ of $1.1 \mathrm{~mW} \mathrm{~m}^{-2}$ for methane, $0.33 \mathrm{~mW} \mathrm{~m}^{-2}$ for ozone and $0.17 \mathrm{~mW} \mathrm{~m}^{-2}$ for stratospheric $\mathrm{H}_{2} \mathrm{O}$.

\subsection{Black carbon}

The impacts on the tropospheric column of black carbon from Arctic shipping and petroleum are shown in Fig. 5a and $\mathrm{b}$. Because of the lifetime of $\mathrm{BC}$, which is on the order of days, the perturbations occur near emission locations, for shipping along the coast of Norway, west coast of Greenland and along the Alaska Peninsula, and petroleum in west Russia and east Alaska. Column changes in BC have a much larger amplitude from petroleum than shipping, with an annual mean burden of $4.1 \mu \mathrm{g} \mathrm{m}^{-2}\left(60-90^{\circ} \mathrm{N}\right) \mathrm{com}-$ pared to $0.38 \mu \mathrm{g} \mathrm{m}^{-2}\left(60-90^{\circ} \mathrm{N}\right)$ due to shipping (Table 2). The higher $\mathrm{BC}$ emissions from petroleum and the limited emission area, leads to a higher black carbon burden, and a high maximum value $\left(\sim 80 \mu \mathrm{g} \mathrm{m}^{-2}\right)$. RF from petroleum 
emissions in the Arctic is also higher (about 10 times) than from shipping, $6.5 \mathrm{~mW} \mathrm{~m}^{-2}$ and $0.60 \mathrm{~mW} \mathrm{~m}^{-2}\left(60-90^{\circ} \mathrm{N}\right)$, respectively.

Balkanski et al. (2010) calculated direct aerosol RF for global transport emissions in year 2000. In the following sections we compare with those values obtained using the same CTM and RF model as in this study. The global mean RF for $\mathrm{BC}$ in air from Arctic shipping (this study) is $3.6 \%$ of total shipping global mean RF for BC in air found in Balkanski et al. (2010) $\left(2.2 \mathrm{~mW} \mathrm{~m}^{-2}\right)$.

Black carbon deposited on snow and ice alters the albedo, which accelerates the melting process in spring (Flanner et al., 2007), and can warm the surface. The RF from BC on snow is $20 \mathrm{~mW} \mathrm{~m}^{-2}\left(60-90^{\circ} \mathrm{N}\right)$ for petroleum activity, and $0.47 \mathrm{~mW} \mathrm{~m}^{-2}\left(60-90^{\circ} \mathrm{N}\right)$ due to shipping (Fig. 5, c and d). The large difference stems from different magnitude of emissions, but also in the fact that shipping occur mainly during months where snow and ice-extension is at it lowest, while emissions from petroleum occur throughout the year. There is no sunlight in winter and thus no effect on RF from black carbon on snow, however BC accumulates in the snow over the winter. In spring, when the snow starts to melt, BC reappears and absorbs sunlight, affecting the radiative budget.

\subsection{Organic carbon}

For concentration changes in organic carbon (OC), the spatial extent is similar to black carbon (not shown here). However, the two carbonaceous compounds have different optical properties. Whereas BC is an absorbing aerosol, OC scatters sunlight. The OC values are however weak; $-0.13 \mathrm{~mW} \mathrm{~m}^{-2}$ from shipping and $-0.42 \mathrm{~mW} \mathrm{~m}^{-2}(60-$ $90^{\circ} \mathrm{N}$ ) from petroleum. This is in part because of the low emission volume, in part because scattering aerosols are less efficient over bright surfaces. Global mean OC RF here yields $1.5 \%$ of the OC RF for total shipping found in Balkanski et al. (2010).

\subsection{Sulphur}

Shipping contributes a much higher share of the Arctic $\mathrm{SO}_{2}$ emissions than petroleum activity. This is shown in Fig. 6, which shows column change of $\mathrm{SO}_{4}$ in January-FebruaryMarch and July-August-September. $\mathrm{SO}_{4}$ is formed by the oxidation of $\mathrm{SO}_{2}$ and is the dominant aerosol component from shipping emissions. It is also one of the most important contributors to RF from shipping, together with the indirect effect where sulphur contributes greatly (Fig. 7). The $\mathrm{SO}_{4}$ direct aerosol effect has a negative forcing because it reflects incoming solar radiation. The RF from shipping in the Arctic is $-5.8 \mathrm{~mW} \mathrm{~m}^{-2}\left(60-90^{\circ} \mathrm{N}\right)$ and the first indirect aerosol effect $-19 \mathrm{~mW} \mathrm{~m}^{-2}$, see Table 2 . $\mathrm{SO}_{2}$ emissions from shipping are high because of the high average sulphur content in marine heavy fuels used by most ocean-going ships (Endresen et al., 2005). For some summer months, changes in
Table 3. Global Radiative Forcing normalized to annual, global change in atmospheric burden $\left[\mathrm{W} \mathrm{g}^{-1}\right]$ and $\left[\mathrm{mW} \mathrm{m}^{-2} \mathrm{DU}^{-1}\right]$ for $\mathrm{O}_{3}$ from ship and petroleum activity in 2004 .

\begin{tabular}{lrr}
\hline & \multicolumn{2}{c}{ Normalized RF $\left[\mathrm{W} \mathrm{g}^{-1}\right]$} \\
\cline { 2 - 3 } Component & Shipping & Petroleum \\
\hline Sulphate & -320 & -232 \\
Nitrate & -206 & -102 \\
BC air & 1630 & 1790 \\
OC & -118 & -121 \\
Ozone $\left(\mathrm{mW} \mathrm{m}^{-2} \mathrm{DU}^{-1}\right)$ & 22 & 27 \\
\hline
\end{tabular}

both oxidant levels and $\mathrm{SO}_{2}$ emissions lead to net burden changes that are close to zero. However, the RFs may still be non-negligible due to vertical changes in sulfate, which leads to high ratios between RF and burden changes. Balkanski et al. (2010) found the direct mean global RF for $\mathrm{SO}_{4}$ from total shipping to be $-29.2 \mathrm{~mW} \mathrm{~m}^{-2}$, which makes the Arctic shipping contribution found here (global mean) $1.5 \%$ of total shipping.

The Arctic emission of $\mathrm{SO}_{2}$ from petroleum extraction (Table 1) results in RF from $\mathrm{SO}_{4}$ direct aerosol effect of $-1.9 \mathrm{~mW} \mathrm{~m}^{-2}\left(60-90^{\circ} \mathrm{N}\right)$ (Table 2), and the indirect aerosol effect is $-2.0 \mathrm{~mW} \mathrm{~m}^{-2}$.

\subsection{Nitrate}

Effects on nitrate are calculated, but are negligible in magnitude. Shipping global mean RF is $0.26 \%$ of total anthropogenic RF found in Myhre et al. (2009), and petroleum RF global mean is $<1 \%$ of total anthropogenic RF.

\section{Discussion}

In terms of forcing, the difference in the amount of components emitted results in different responses. Shipping has larger $\mathrm{NO}_{\mathrm{x}}$ and $\mathrm{SO}_{2}$ emissions, while petroleum has larger emissions of black carbon. Negative RF from sulphate (direct and indirect) dominates the response from shipping, while positive RF from black carbon, both in air through the direct aerosol effect and deposited on snow, gives the largest effect from petroleum emission (Fig. 7 and Table 2). Inequality in location and seasonality of the emissions also play a role, in a region characterized by large seasonal differences. Thus, when only short-lived climate forcers, SLCF, are considered (i.e. not $\mathrm{CO}_{2}$ ), shipping emissions exert a net negative RF while the net effect from petroleum is positive.

\subsection{Normalized forcing}

Radiative forcing per unit of burden change, i.e. normalized forcing (NRF) is a useful diagnostic to analyze the processes that governs the radiative forcing. Normalized forcing with 
a)
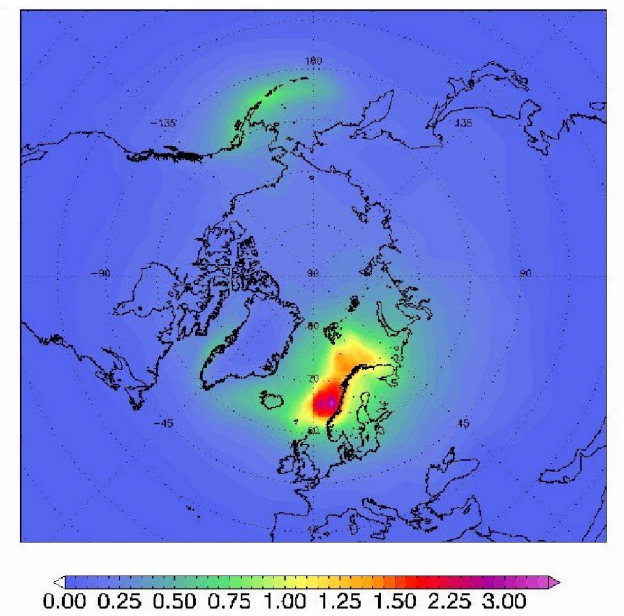

c)

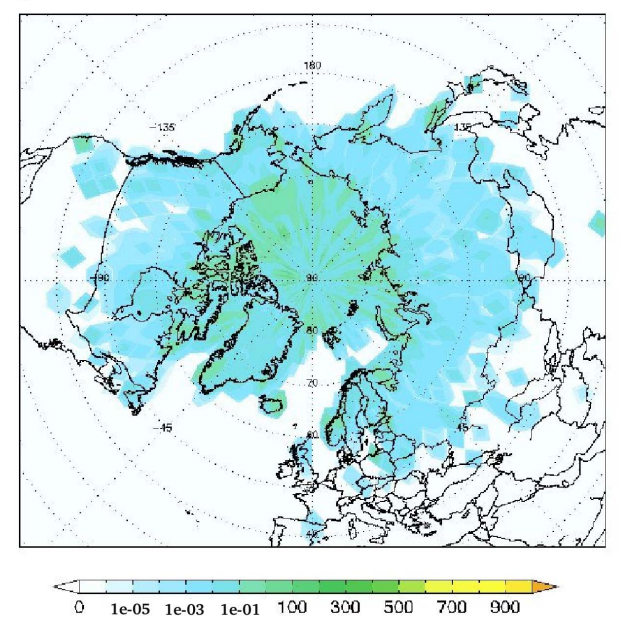

b)

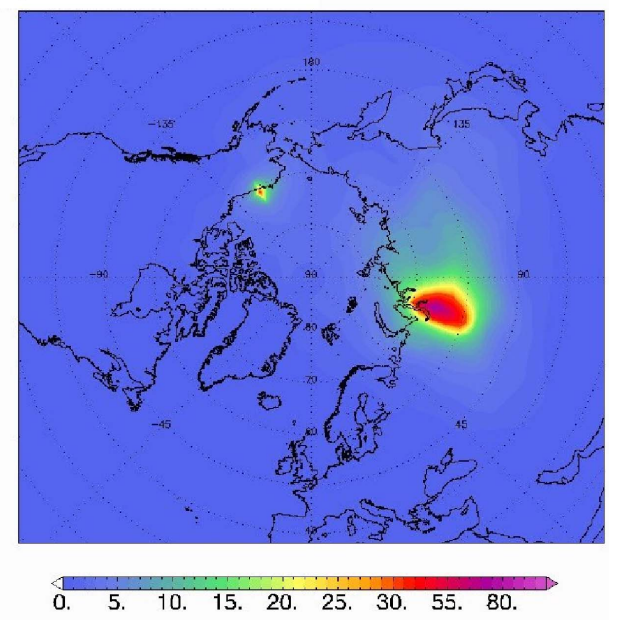

d)

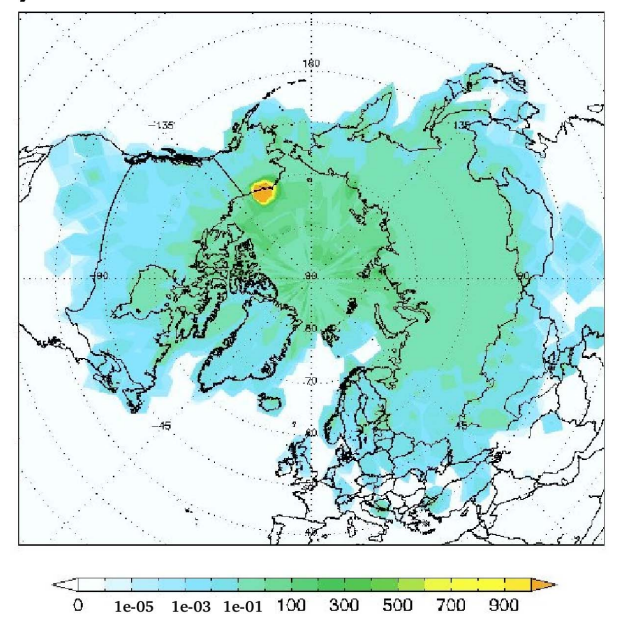

Fig. 5. BC effects from Arctic shipping and petroleum emissions. (a) Contribution to tropospheric column of black carbon [ $\left.\mu \mathrm{g} \mathrm{m}^{-2}\right]$ from Arctic shipping activity in 2004. (b) Contribution to tropospheric column of black carbon $\left[\mu \mathrm{g} \mathrm{m}^{-2}\right.$ ] from Arctic petroleum activity in 2004. (c) Radiative Forcing from black carbon on snow $\left[\mathrm{mW} \mathrm{m}^{-2}\right]$ from Arctic shipping activity in 2004. (d) Radiative Forcing from black carbon on snow $\left[\mathrm{mW} \mathrm{m}^{-2}\right.$ ] from Arctic petroleum activity in 2004.

respect to change in atmospheric burden is shown in Table 3 and in Figs. 8 and 9. Figure 8 shows seasonal variations of RF from aerosols and ozone, for shipping and petroleum. The leftmost plots show major contributors to the total RF, the rightmost plots show weaker effects. Ozone is a special case, in that the dashed blue line for NRF is shown in $\mathrm{W} \mathrm{m}^{-2} \mathrm{DU}^{-1}$ rather than $\mathrm{Wg}^{-1}$. The insets show the two strongest effects separately, i.e. the indirect aerosol effect for shipping (panel a), and the effect from $\mathrm{BC}$ on show for petroleum (panel d).

Most RF from SLCF peak during the summer months, when the Arctic receives the most sunlight. This is also apparent from the normalized forcing curves (dashed). A few notable points should be mentioned. The periods of high ratio between $\mathrm{SO}_{4} \mathrm{RF}$ and burden in the summer months, due to changes in oxidant levels as discussed in Sect. 3.5, can be seen in the strong sulphate normalized forcing.
Likewise the enhanced NRF for ozone during winter, especially for petroleum, is due to reduced ozone at low altitudes near the sources.

The NRF of direct aerosol effect of BC has its peak earlier than for the direct aerosol effect of sulphate due to higher surface albedo with more snow and sea ice in early summer than late summer. We also note that the indirect effect systematically peaks later in the summer than aerosol direct forcing, likely due to higher fraction of water clouds.

Figure 9 indicates the regional and seasonal variations in normalized RF for $\mathrm{BC}(\mathrm{a}, \mathrm{b}), \mathrm{OC}(\mathrm{c}, \mathrm{d})$ and $\mathrm{O}_{3}(\mathrm{e}, \mathrm{f})$ from shipping emissions. The left hand panels show winter months (JFM) with little sunlight in the Arctic region, while right hand panels show subsequent months with more sunlight (AMJ). For BC, an absorbing aerosol, we note how the NRF vanishes when there is little sunlight but then becomes very strong in areas with snow cover when the sun comes 
a)

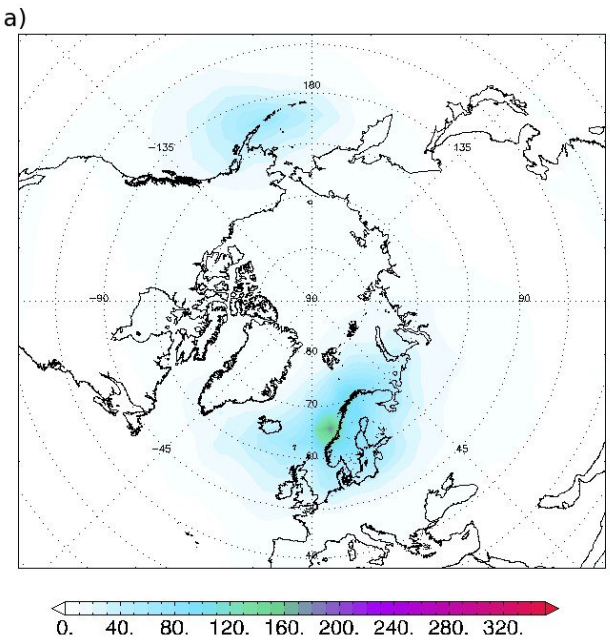

c)

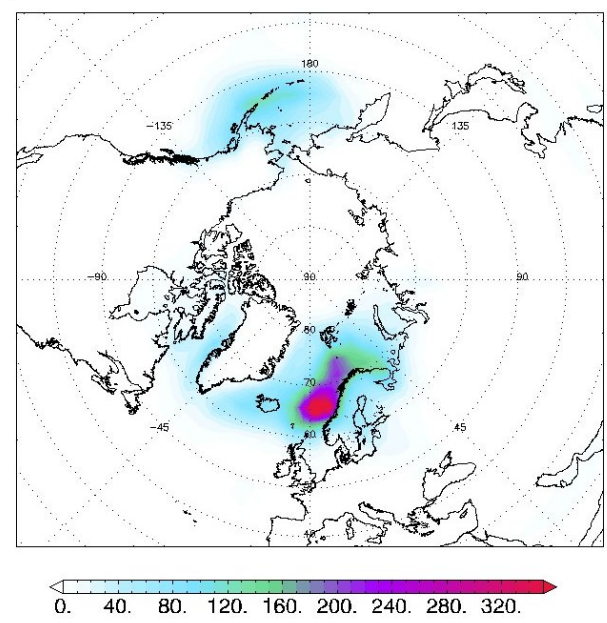

b)

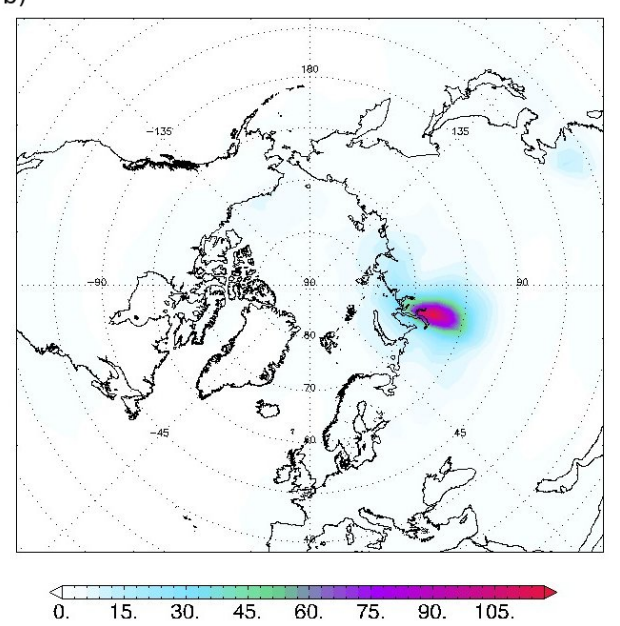

d)

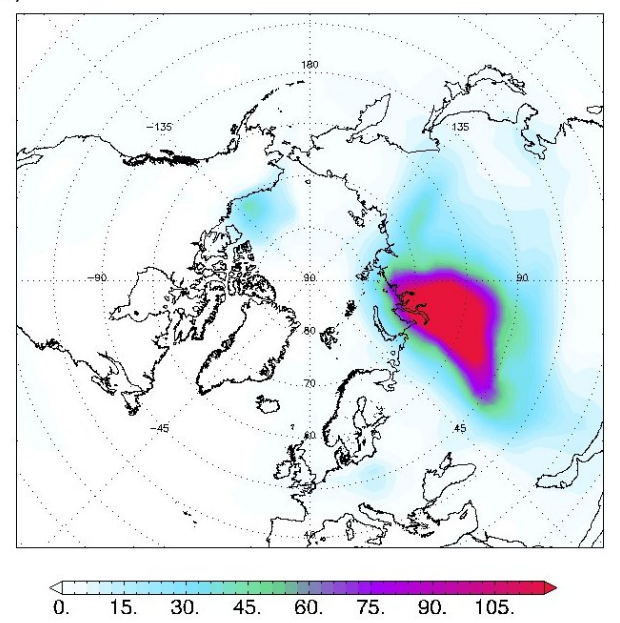

Fig. 6. Contribution to tropospheric column of sulphate $\left[\mu \mathrm{g} \mathrm{m}^{-2}\right]$ from (a) shipping and (b) petroleum in winter (January-February-March) and (c) shipping and (d) petroleum activity in summer (July-September-August) (note that the figures for shipping and petroleum have different color scales).

Table 4. GWP values for shipping and petroleum emissions (global mean) for 20, 100 and 500 yr time horizons. Sulphate is calculated on $\mathrm{SO}_{2}$ basis (not S-basis).

\begin{tabular}{lrrrrrrr}
\hline & \multicolumn{5}{c}{ GWP } \\
\cline { 2 - 4 } & \multicolumn{3}{c}{ Shipping } & & \multicolumn{3}{c}{ Petroleum } \\
\cline { 2 - 4 } \cline { 6 - 8 } Component & $H=20$ & $H=100$ & $H=500$ & & $H=20$ & $H=100$ & $H=500$ \\
\hline Sulphate & -47 & -13 & -4 & & -64 & -18 & -5 \\
Indirect* & -205 & -58 & -18 & & & \\
BC air & 2037 & 579 & 176 & & 2369 & 673 & 205 \\
BC snow & 764 & 217 & 66 & & 4104 & 1166 & 354 \\
OC & -151 & -43 & -13 & & -152 & -43 & -13 \\
\hline
\end{tabular}

* For shipping, the GWP calculations for indirect aerosol effect are attributed to $\mathrm{SO}_{2}$ emissions. Note that the indirect aerosol effect is calculated including all the aerosols, but sulphate is the dominating contributer. Due to significant contributions from $\mathrm{BC}$ and $\mathrm{OC}$, in addition to $\mathrm{SO}_{2}$, we do not attribute the indirect effect to one single component for emissions from petroleum activity. 


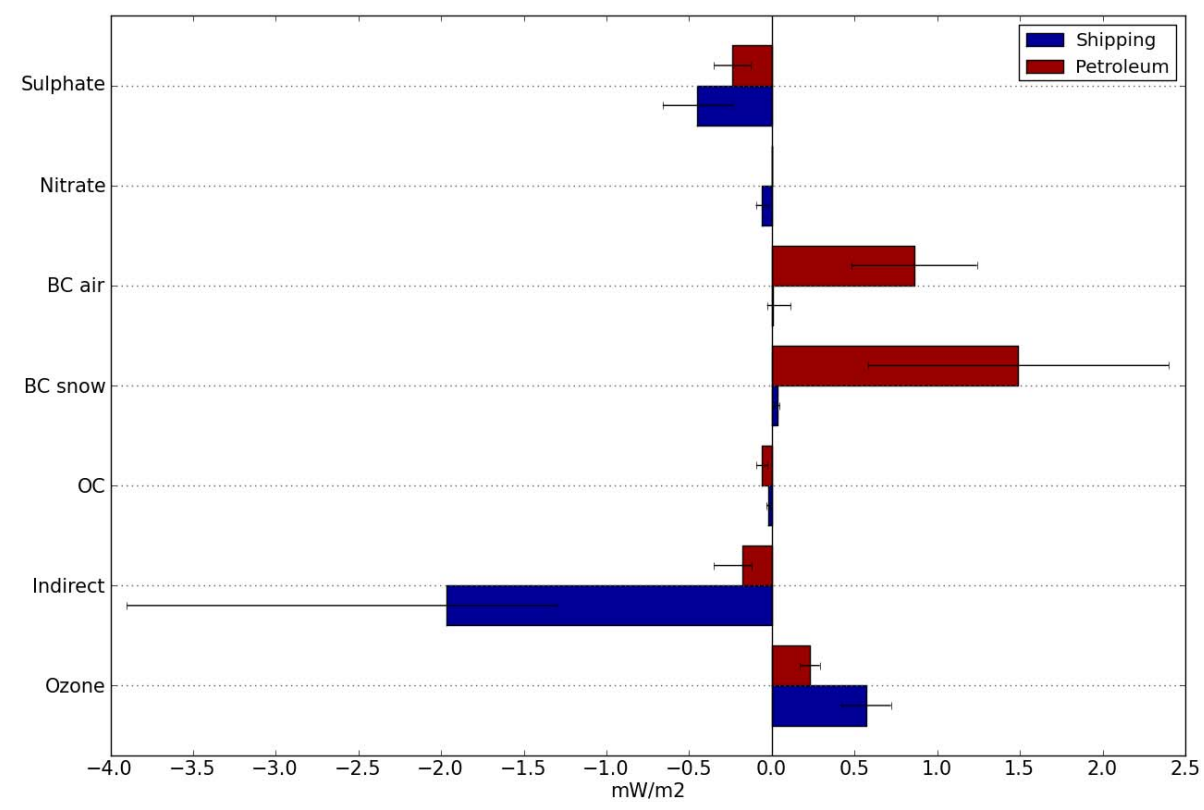

Fig. 7. Global and annual radiative forcing $\left[\mathrm{mW} \mathrm{m}^{-2}\right]$ for the different short lived components from shipping and petroleum emissions. The error-bars imply uncertainties in the estimated RF.

back. Surrounding, non-snow aeras also strengthen, but not to the same degree. For OC, a scattering aerosol, the same trend of NRF strengthening with sunlight holds, but the specific effect of snow cover is not seen. Actually a weakening of NRF of OC is seen over snow and ice. For $\mathrm{O}_{3}$, which has a general dominant longwave effect, there is a strengthening in the summer from a shortwave contribution as well as enhanced longwave effect.

Comparing with other studies, Myhre et al. (2011) found ozone NRF from shipping to be $30 \mathrm{~mW} \mathrm{~m}^{-2} \mathrm{DU}^{-1}$ (range from 29 to 32). The global mean value simulated for shipping activity is weaker, namely $22 \mathrm{~mW} \mathrm{~m}^{-2} \mathrm{DU}^{-1}$. For emissions from petroleum the NRF value is $27 \mathrm{~mW} \mathrm{~m}^{-2} \mathrm{DU}^{-1}$ (global mean). Berntsen et al. (2006) compared the potential climate effects of mitigation measures applied to various regions and found $\mathrm{O}_{3} \mathrm{NRF}$ s to be $35,40,38,37 \mathrm{~mW} \mathrm{~m}^{-2} \mathrm{DU}^{-1}$ for $\mathrm{Eu}-$ rope, China, South Asia and South America, respectively. The lower NRF for ozone from shipping and petroleum in the Arctic than for emissions of ozone precursors in other regions is expected because of the low longwave part of NRF of ozone in the Arctic due to low surface temperatures and relatively small difference between the surface temperature and the tropopause temperature.

Berntsen et al. (2006) found sulphate NRFs for the same regions to be $-213,-186,-224$ and $-268 \mathrm{Wg}^{-1}$. Normalized sulphate from Arctic shipping is somewhat stronger than for all of these regions ( -320 , see Table 3), while Arctic petroleum NRF (global mean: -232) is stronger than all the regions except South America. Compared with numbers for total anthropogenic emissions of sulphate in Myhre et al.
(2009) ( $-227 \mathrm{~W} \mathrm{~g} \mathrm{~g}^{-1}$ ), the normalized RF for Arctic shipping emissions are somewhat stronger.

The main reason for the stronger NRF is again that we have short periods with a low sulphate burden change but negligible RF (see Sect. 3.5), which dominate the global mean value. In addition, factors such as water uptake of aerosols due to high relative humidity, low albedo of sea water, and the fact that a large fraction of the emissions occurs during summer, also strengthen the sulphate NRF for Arctic shipping.

Sulphate NRF from petroleum is closer to the Myhre et al. (2009) value. NRFs for black carbon found here (Table 3) are comparable with $1693 \mathrm{~W} \mathrm{~g}^{-1}$ found in Myhre et al. (2009). In the present work, global means of 1630 and $1790 \mathrm{~W} \mathrm{~g}^{-1}$ are found from Arctic shipping and petroleum, respectively. We find OC NRFs to be weaker; $-118 \mathrm{~W} \mathrm{~g}^{-1}$ (shipping) and $-121 \mathrm{~W} \mathrm{~g}^{-1}$ (petroleum) compared to $-273 \mathrm{~W} \mathrm{~g}^{-1}$ in Myhre et al. (2009). Nitrate NRFs are comparable for shipping; $-208 \mathrm{~W} \mathrm{~g}^{-1}$ (Myhre et al., 2009) and $-206 \mathrm{~W} \mathrm{~g}^{-1}$ (global mean) here, while petroleum is weaker, with a value of $-102 \mathrm{~W} \mathrm{~g}^{-1}$. The BC NRF for Arctic emissions is similar to global emissions due to the low annual solar radiation compensating for high surface albedo. High surface albedo and lower solar irradiance reduces the NRF for emissions of scattering aerosol in the Arctic compared to global emissions, as seen for OC. For nitrate and sulphate, which are more hygroscopic than $\mathrm{OC}$, the generally high relative humidity in the Arctic strengthens the NRF. 

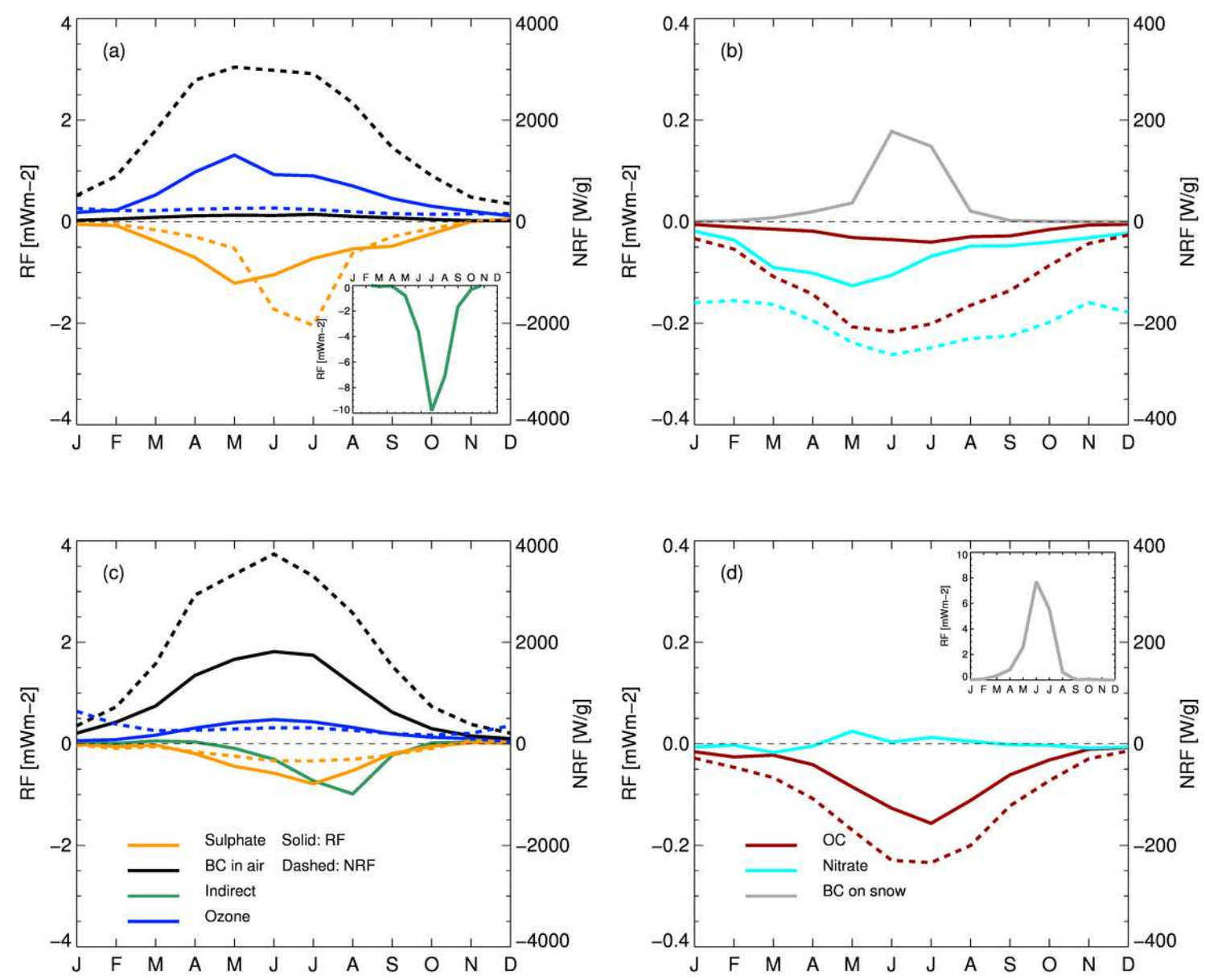

Fig. 8. Seasonal variations of RF (solid lines) and NRF (dashed lines) from sulphate, BC in air, BC on snow, OC, nitrate and aerosol indirect effect. Panels (a) and (b) show shipping, panels (c) and (d) show petroleum. Separation into left and right panels and use of insets is for clarity only. Ozone NRF has units of $\mathrm{W} \mathrm{m}^{2} \mathrm{DU}^{-1}$, and has been scaled by a factor of 10 for clarity.

\subsection{Global warming potential}

Based on the concept of Radiative Forcing, the Intergovernmental Panel on Climate Change (IPCC) has employed the metric GWP (Global Warming Potential) as a tool to quantify and compare the potential impact of different climate change agents (Forster et al., 2007). GWP is a metric defined as the integrated RF caused by a pulse emission of $1 \mathrm{~kg}$ of a trace gas, $i$, over a chosen time horizon, relative to the RF of $1 \mathrm{~kg}$ of the reference gas $\mathrm{CO}_{2}$ :

$\operatorname{GWP}(H)_{i}=\frac{\int_{0}^{H} \mathrm{RF}_{i}(t) \mathrm{d} t}{\int_{0}^{H} \mathrm{RF}_{\mathrm{CO}_{2}}(t) \mathrm{d} t}$

where $H$ is the chosen time frame. Table 4 gives GWP for $\mathrm{BC}, \mathrm{OC}, \mathrm{SO}_{4}$ and indirect aerosol effects from shipping and petroleum on time frames of 20, 100 and $500 \mathrm{yr}$. Note that here the GWPs for sulphate are also influenced by changes in oxidation rates due to the co-emitted species. GWPs for $\mathrm{BC}$ in air are comparable for shipping and petroleum, while for $\mathrm{BC}$ on snow the GWPs are about 4 times stronger for petroleum than shipping. Also, for sulphate the two sectors are comparable. GWPs for OC are comparable for shipping and petroleum.

Values for BC GWP found in Bond et al. (2011) are comparable to our numbers for $\mathrm{BC}$ in air. The GWPs found here for $\mathrm{BC}$ in air are somewhat higher than the global GWPs in Fuglestvedt et al. (2010). The OC values are comparable to Fuglestvedt et al. (2010), while $\mathrm{SO}_{2}$ GWPs are lower than what is found in their study. The values in Fuglestvedt et al. (2010) are for a global perturbation and a different model. Large differences in model methods to calculate RF exist. Therefore, the GWP difference cannot be interpreted as different sensitivity for Arctic emissions. NRF comparison with previous studies using the same CTM and RF model is discussed in Sect. 4.1.

The GWPs for the short-lived components given in Table 4 can be used to make first-order assessments of the global impact of changing emissions from the shipping and petroleum sectors in the Arctic. The net impact in terms of changes in " $\mathrm{CO}_{2}$-equivalent" emissions for any given 
a)
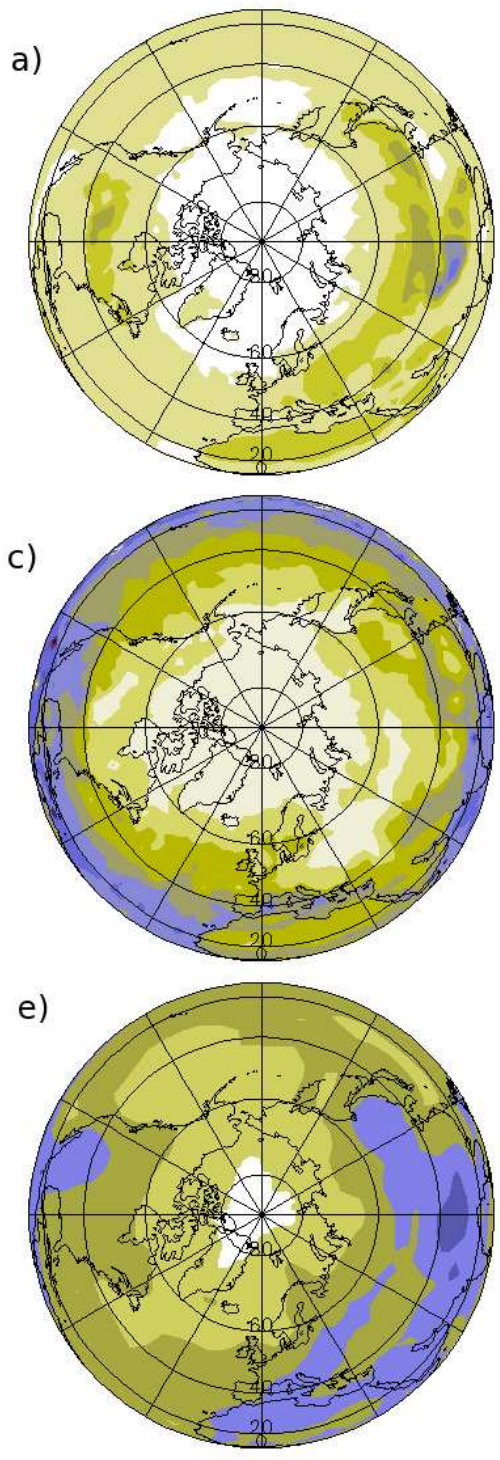
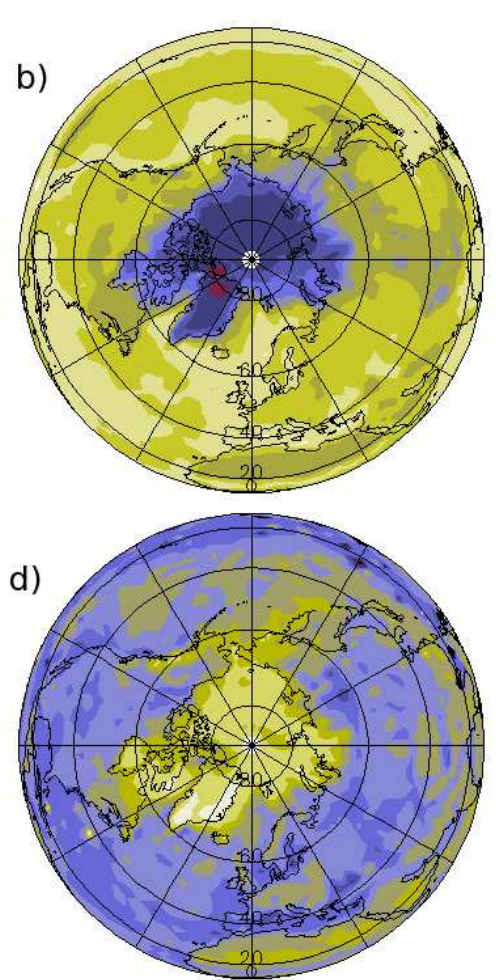

f)

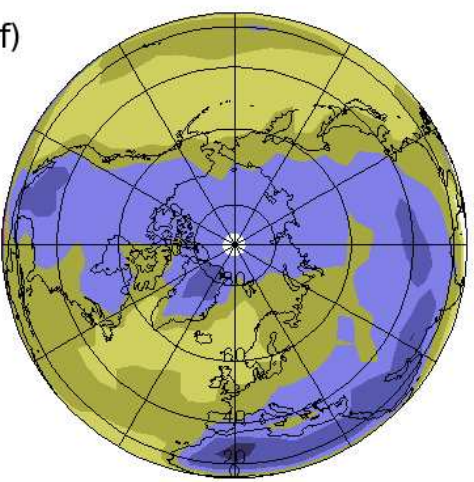

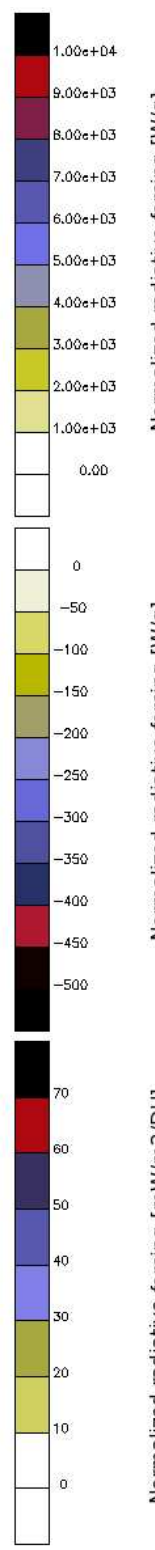

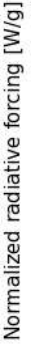

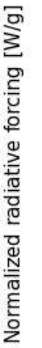

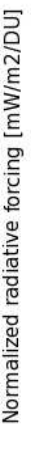

Fig. 9. Seasonal dependence of normalized radiative forcing for $\mathrm{BC}(\mathbf{a}, \mathbf{b}), \mathrm{OC}(\mathbf{c}, \mathbf{d})$ and $\mathrm{O}_{3}(\mathbf{e}, \mathbf{f})$ from shipping emissions. Left hand panels show January-March when there is little sunlight in the Arctic region, right hand panels show April-June when sunlight is more prevalent.

scenario, including LLGHGs with GWPs from IPCC (2007), can be derived by calculating the sum of the GWP-weighted emissions for all components.

\subsection{Uncertainties}

The main results from this work are given in Table 2 in terms of RF for the different components. Based on the available information it is not possible to perform a formal uncertainty propagation from emissions through CTM calculations of concentrations and radiative transfer simulations. To estimate the uncertainty in the RF numbers we therefore have to rely on estimates from other studies that of- ten have a more global focus and make a subjective adjustment to the individual uncertainties for the Arctic region. Peters et al. (2011) do not estimate uncertainties in the emission factors for 2004 emissions. For the emissions we apply the same relative, component specific, uncertainties as were used for the shipping sector in Fuglestvedt et al. (2008). For the RF by sulphate, $\mathrm{BC}$ and $\mathrm{OC}$ aerosols we use the multimodel $1-\sigma$ range of global mean RFs from model simulation with equal emissions from the AEROCOM project (Schulz et al., 2006). For nitrate aerosols, BC on snow and the indirect effect of aerosols we apply the range given by IPCC (Forster et al., 2007, Table 2.12), while for ozone we apply 
the same relative uncertainties that were used in Fuglestvedt et al. (2008) for the shipping sector. The uncertainties are given in Fig. 7. There are some Arctic or sector specific factors that could add to the uncertainties, but are not included in the estimates due to lack of information. This includes potentially higher uncertainties in the activity data and emission factors for shipping and petroleum exploration at high latitudes, impact of large variability in surface albedoes and non-linear effects in ship plumes (e.g. Huszar et al., 2010).

\section{Conclusions}

Emissions of short-lived compounds from shipping and petroleum activities in the Arctic have effects on concentration levels of several gases and aerosols and lead directly and indirectly to radiative forcing. The composition, annual cycle and geographical distribution of the emissions leads to pronounced differences between the two sectors. For shipping, high emissions of $\mathrm{SO}_{2}$, and the maximum in emissions during summer, means that the radiative forcing is dominated by the direct effect of sulphate aerosols and the first indirect aerosol effect. For petroleum emissions sulphur emissions are much lower while the $\mathrm{BC}$ emissions are higher, and the emissions are evenly distributed annually. For this sector the $\mathrm{BC}$ deposited on snow, predominately within the Arctic region, exerts the largest radiative forcing, followed by the direct aerosol effect of BC. Due to higher $\mathrm{NO}_{\mathrm{x}}$ emissions and maximum emissions during summer, concentration changes and radiative forcing for ozone are stronger for shipping than for petroleum.

In terms of net forcing we find that the effect of Arctic shipping emissions of SLCFs and precursors is negative, while the net effect from Arctic petroleum emissions of SLCFs is positive. The regional radiative forcings north of $60^{\circ} \mathrm{N}$ are of the order of $-20 \mathrm{~mW} \mathrm{~m}^{-2}$ and $+20 \mathrm{~mW} \mathrm{~m}^{-2}$, respectively. To assess the overall effects of shipping and petroleum in the Arctic also the impact of the emissions of the intermediate and long-lived components methane and carbon dioxide must be taken into account. However, for these components the location of the emissions is unimportant.

The physical conditions in the Arctic including, high solar angle, high surface albedo, summer season with midnight sun and polar night during winter are very different from other regions of the World. However, the normalized forcings, e.g. to change in atmospheric burden (NRF), or to emissions as in the GWPs, suggest that the annual averaged sensitivities for Arctic emissions, with BC on snow and ice as a notable exception, are similar to the global averages. The seasonal cycle in the sensitivities and thus in the radiative forcings is, however, much more pronounced.

The melting of Arctic sea ice will unlock the Arctic ocean areas, leaving it increasingly open to human activity. Particularly shipping and petroleum production are expected to change. Here we have investigated the effects of current shipping- and petroleum emissions. Future emissions could potentially have a significant effect on Arctic environment, regional air pollution levels and radiative budget. This will be addressed in upcoming studies.

Acknowledgements. This work was funded by the Norwegian Research Council (project number 184873/S30, "Unlocking the Arctic Ocean: the climate impact of increased shipping and petroleum acticities (ArcAct)").

Edited by: N. Riemer

\section{References}

ACIA: Arctic Climate Impact Assessment, Cambridge University Press, 2005.

Balkanski, Y., Myhre, G., Gauss, M., Rädel, G., Highwood, E. J., and Shine, K. P.: Direct radiative effect of aerosols emitted by transport: from road, shipping and aviation, Atmos. Chem. Phys., 10, 4477-4489, doi:10.5194/acp-10-4477-2010, 2010.

Berglen, T., Berntsen, T., Isaksen, I., and Sundet, J.: A global model of the coupled sulfur/oxidant chemistry in the troposphere: The sulfur cycle, J. Geophys. Res.-Atmos., 109, D19310, doi:10.1029/2003JD003948, 2004.

Berntsen, T. and Isaksen, I.: A global three-dimensional chemical transport model for the troposphere .1. Model description and CO and ozone results, J. Geophys. Res.-Atmos., 102, 2123921280, doi:10.1029/97JD01140, 1997.

Berntsen, T., Fuglestvedt, J., Joshi, M., Shine, K., Stuber, N., Ponater, M., Sausen, R., Hauglustaine, D., and Li, L.: Response of climate to regional emissions of ozone precursors: sensitivities and warming potentials, Tellus B, 57, 283-304, 2005.

Berntsen, T., Fuglestvedt, J., Myhre, G., Stordal, F., and Berglen, T.: Abatement of greenhouse gases: Does location matter?, Climatic Change, 74, 377-411, doi:10.1007/s10584-006-0433-4, 2006.

Bond, T. C., Zarzycki, C., Flanner, M. G., and Koch, D. M.: Quantifying immediate radiative forcing by black carbon and organic matter with the Specific Forcing Pulse, Atmos. Chem. Phys., 11, 1505-1525, doi:10.5194/acp-11-1505-2011, 2011.

Corbett, J., Winebrake, J., Green, E., Kasibhatla, P., Eyring, V., and Lauer, A.: Mortality from ship emissions: A global assessment, Environ. Sci. Technol., 41, 8512-8518, 2007.

Corbett, J. J., Lack, D. A., Winebrake, J. J., Harder, S., Silberman, J. A., and Gold, M.: Arctic shipping emissions inventories and future scenarios, Atmos. Chem. Phys., 10, 9689-9704, doi:10.5194/acp-10-9689-2010, 2010.

Dalsøren, S. B., Endresen, Ø., Isaksen, I. S. A., Gravir, G., and Sørgård, E.: Environmental impacts of the expected increase in sea transportation, with a particular focus on oil and gas scenarios for Norway and northwest Russia, J. Geophys. Res.-Atmos., 112, D02310, doi:10.1029/2005JD006927, 2007.

Dalsøren, S. B., Eide, M. S., Endresen, Ø., Mjelde, A., Gravir, G., and Isaksen, I. S. A.: Update on emissions and environmental impacts from the international fleet of ships: the contribution from major ship types and ports, Atmos. Chem. Phys., 9, 2171-2194, doi:10.5194/acp-9-2171-2009, 2009.

Dalsøren, S. B., Eide, M. S., Myhre, G., Endresen, Ø., Isaksen, I. S. A., and Fuglestvedt, J. S.: Impacts of the Large 
Increase in International Ship Traffic 2000-2007 on Tropospheric Ozone and Methane, Environ. Sci. Technol., 44, 24822489, doi:10.1021/es902628e, 2010.

Derwent, R., Collins, W. J., Johnson, C., and Stevenson, D. S.: Transient Behaviour of Tropospheric Ozone Precursors in a Global 3-D CTM and Their Indirect Greenhouse Effects., Climatic Change, 49, 463-487, 2001.

Endresen, Ø., Sørgård, E., Sundet, J. K., Dalsøren, S. B., Isaksen, I. S. A., Berglen, T. F., and Gravir, G.: Emission from International sea transportation and environmental impact, J. Geophys. Res., 108, 4560, doi:10.1029/2002JD002898, 2003.

Endresen, Ø., Bakke, J., Sørgård, E., Berglen, T., and Holmvang, P.: Improved modelling of ship $\mathrm{SO}_{2}$ emissions - a fuel based approach, Atmos. Environ., 39, 3621-3628, 2005.

Eyring, V., Isaksen, I., Berntsen, T., Collins, W., Corbett, J., Endresen, O., Grainger, R., Moldanova, J., Schlager, H., and Stevenson, D.: Transport impacts on atmosphere and climate: Shipping, Atmos. Environ., 44, 4735-4771, doi:10.1016/j.atmosenv.2009.04.059, 2010.

Flanner, M. G., Zender, C. S., Randerson, J. T., and Rasch, P. J.: Present-day climate forcing and response from black carbon in snow, J. Geophys. Res.-Atmos., 112, D11202, doi:10.1029/2006JD008003, 2007.

Forster, P., Ramaswamy, V., Artaxo, P., Berntsen, T., Betts, R., Fahey, D., Haywood, J., Lean, J., Lowe, D., Myhre, G., Nganga, J., Prinn, R., Raga, G., Schulz, M., and Van Dorland, R.: Changes in Atmospheric Constituents and in Radiative Forcing, Climate Change 2007: The Physical Science Basis. Contribution of Working Group I to the Fourth Assessment Report of the Intergovernmental Panel on Climate Change, Cambridge University Press, Cambridge, United Kingdom and New York, NY, USA, 2007.

Fuglestvedt, J., Berntsen, T., Myhre, G., Rypdal, K., and Skeie, R. B.: Climate forcing from the transport sectors, P. Natl. Acad. Sci. USA, 105, 454-458, doi:10.1073/pnas.0702958104, 2008.

Fuglestvedt, J. S., Berntsen, T., Isaksen, I. S. A., Mao, H., Liang, X.-Z., and Wang, W.-C.: Climatic forcing of nitrogen oxides through changes in tropospheric ozone and methane; global 3D model studies, Atmos. Environ., 33, 961-977, 1999.

Fuglestvedt, J. S., Shine, K. P., Berntsen, T., Cook, J., Lee, D. S., Stenke, A., Skeie, R. B., Velders, G. J. M., and Waitz, I. A.: Transport impacts on atmosphere and climate: Metrics, Atmos. Environ., 44, 4648-4677, doi:10.1016/j.atmosenv.2009.04.044, 2010.

Granier, C., Niemeier, U., Jungclaus, J. H., Emmons, L., Hess, P., Lamarque, J.-F., Walters, S., and Brasseur, G. P.: Ozone pollution from future ship traffic in the Arctic northern passages, Geophys. Res. Lett., 33, L13807, doi:10.1029/2006GL026180, 2006.

Hansen, J. and Nazarenko, L.: Soot climate forcing via snow and ice albedos, P. Natl. Acad. Sci. USA, 101, 423-428, doi:10.1073/pnas.2237157100, 2004.

Haywood, J. and Shine, K.: Multi-spectral calculations of the direct radiative forcing of tropospheric sulphate and soot aerosols using a column model, Q. J. Roy. Meteorol. Soc., 123, 1907-1930, doi:10.1002/qj.49712354307, 1997.

Huszar, P., Cariolle, D., Paoli, R., Halenka, T., Belda, M., Schlager, H., Miksovsky, J., and Pisoft, P.: Modeling the regional impact of ship emissions on $\mathrm{NO}_{\mathrm{x}}$ and ozone levels over the Eastern At- lantic and Western Europe using ship plume parameterization, Atmos. Chem. Phys., 10, 6645-6660, doi:10.5194/acp-10-66452010, 2010.

Isaksen, I. S. A., Granier, C., Myhre, G., Berntsen, T. K., Dalsoren, S. B., Gauss, M., Klimont, Z., Benestad, R., Bousquet, P., Collins, W., Cox, T., Eyring, V., Fowler, D., Fuzzi, S., Joeckel, P., Laj, P., Lohmann, U., Maione, M., Monks, P., Prevot, A. S. H., Raes, F., Richter, A., Rognerud, B., Schulz, M., Shindell, D., Stevenson, D. S., Storelvmo, T., Wang, W. C., van Weele, M., Wild, M., and Wuebbles, D.: Atmospheric composition change: Climate-Chemistry interactions, Atmos. Environ., 43, 5138-5192, doi:10.1016/j.atmosenv.2009.08.003, 2009.

Koch, D., Schulz, M., Kinne, S., McNaughton, C., Spackman, J. R., Balkanski, Y., Bauer, S., Berntsen, T., Bond, T. C., Boucher, O., Chin, M., Clarke, A., De Luca, N., Dentener, F., Diehl, T., Dubovik, O., Easter, R., Fahey, D. W., Feichter, J., Fillmore, D., Freitag, S., Ghan, S., Ginoux, P., Gong, S., Horowitz, L., Iversen, T., Kirkevåg, A., Klimont, Z., Kondo, Y., Krol, M., Liu, X., Miller, R., Montanaro, V., Moteki, N., Myhre, G., Penner, J. E., Perlwitz, J., Pitari, G., Reddy, S., Sahu, L., Sakamoto, H., Schuster, G., Schwarz, J. P., Seland, Ø., Stier, P., Takegawa, N., Takemura, T., Textor, C., van Aardenne, J. A., and Zhao, Y.: Evaluation of black carbon estimations in global aerosol models, Atmos. Chem. Phys., 9, 9001-9026, doi:10.5194/acp-9-9001-2009, 2009.

Lauer, A., Eyring, V., Hendricks, J., Jöckel, P., and Lohmann, U.: Global model simulations of the impact of ocean-going ships on aerosols, clouds, and the radiation budget, Atmos. Chem. Phys., 7, 5061-5079, doi:10.5194/acp-7-5061-2007, 2007.

Lund, M. T. and Berntsen, T.: Parameterization of black carbon aging in the OsloCTM2 and implications for regional transport to the Arctic, Atmos. Chem. Phys. Discuss., 11, 32499-32534, doi:10.5194/acpd-11-32499-2011, 2011.

Myhre, G., Bellouin, N., Berglen, T. F., Berntsen, T. K., Boucher, O., Grini, A., Isaksen, I. S. A., Johnsrud, M., Mishchenko, M. I., Stordal, F., and Tanre, D.: Comparison of the radiative properties and direct radiative effect of aerosols from a global aerosol model and remote sensing data over ocean, Tellus B, 59, 115129, doi:10.1111/j.1600-0889.2006.00226.x, 2007.

Myhre, G., Berglen, T. F., Johnsrud, M., Hoyle, C. R., Berntsen, T. K., Christopher, S. A., Fahey, D. W., Isaksen, I. S. A., Jones, T. A., Kahn, R. A., Loeb, N., Quinn, P., Remer, L., Schwarz, J. P., and Yttri, K. E.: Modelled radiative forcing of the direct aerosol effect with multi-observation evaluation, Atmos. Chem. Phys., 9, 1365-1392, doi:10.5194/acp-9-1365-2009, 2009.

Myhre, G., Shine, K. P., Raedel, G., Gauss, M., Isaksen, I. S. A., Tang, Q., Prather, M. J., Williams, J. E., van Velthoven, P., Dessens, O., Koffi, B., Szopa, S., Hoor, P., Grewe, V., Borken-Kleefeld, J., Berntsen, T. K., and Fuglestvedt, J. S.: Radiative forcing due to changes in ozone and methane caused by the transport sector, Atmos. Environ., 45, 387-394, doi:10.1016/j.atmosenv.2010.10.001, 2011.

Naik, V., Mauzerall, D., Horowitz, L., Schwarzkopf, M., Ramaswamy, V., and Oppenheimer, M.: Net radiative forcing due to changes in regional emissions of tropospheric ozone precursors, J. Geophys. Res.-Atmos., 110, D24306, doi:10.1029/2005JD005908, 2005.

NSIDC: National Snow and Ice Data Center, Arctic sea ice shatters all previous record lows, Arctic Sea Ice News Fall 2007, 2007. 
Olivier, J., Van Aardenne, J., Dentener, F., Ganzeveld, L., and Peters, J.: Recent trends in global greenhouse gas emissions: regional trends and spatial distribution of key sources, Non- $\mathrm{CO}_{2}$ Greenhouse Gases (NCGG-4) Millpress, Rotterdam, ISBN: 90 5966043 9, 2005.

Paxian, A., Eyring, V., Beer, W., Sausen, R., and Wright, C.: Present-Day and Future Global Bottom-Up Ship Emission Inventories Including Polar Routes, Environ. Sci. Technol., 44, 13331339, doi:10.1021/es9022859, 2010.

Penner, J. E., Xu, L., and Wang, M.: Satellite methods underestimate indirect climate forcing by aerosols, P. Natl. Acad. Sci. USA, 108, 13404-13408, doi:10.1073/pnas.1018526108, 2011.

Peters, G. P., Nilssen, T. B., Lindholt, L., Eide, M. S., Glomsrød, S., Eide, L. I., and Fuglestvedt, J. S.: Future emissions from shipping and petroleum activities in the Arctic, Atmos. Chem. Phys., 11, 5305-5320, doi:10.5194/acp-11-5305-2011, 2011.

Quaas, J. and Boucher, O.: Constraining the first aerosol indirect radiative forcing in the LMDZ GCM using POLDER and MODIS satellite data, Geophys. Res. Lett., 32, L17814, doi:10.1029/2005GL023850, 2005.

Quaas, J., Boucher, O., and Lohmann, U.: Constraining the total aerosol indirect effect in the LMDZ and ECHAM4 GCMs using MODIS satellite data, Atmos. Chem. Phys., 6, 947-955, doi:10.5194/acp-6-947-2006, 2006.

Rypdal, K., Rive, N., Berntsen, T. K., Klimont, Z., Mideksa, T. K., Myhre, G., and Skeie, R. B.: Costs and global impacts of black carbon abatement strategies, Tellus B, 61, 625-641, 2009.

Schulz, M., Textor, C., Kinne, S., Balkanski, Y., Bauer, S., Berntsen, T., Berglen, T., Boucher, O., Dentener, F., Guibert, S., Isaksen, I. S. A., Iversen, T., Koch, D., Kirkevåg, A., Liu, X., Montanaro, V., Myhre, G., Penner, J. E., Pitari, G., Reddy, S., Seland, Ø., Stier, P., and Takemura, T.: Radiative forcing by aerosols as derived from the AeroCom present-day and pre-industrial simulations, Atmos. Chem. Phys., 6, 5225-5246, doi:10.5194/acp-6-5225-2006, 2006.
Schultz, M., van het Bolscher, M., Pulles, T., Brand, R., Pereira, J., and Spessa, A.: RETRO report on emission data sets and methodologies for estimating emissions. Workpacage 1, Deliverable D1-6, Tech. rep., EU-Contract No. EVK2-CT-2002-00170, available at: http://retro.enes.org/reports/D1-6_final.pdf, 2007.

Serreze, M. C., Holland, M. M., and Stroeve, J.: Perspectives on the Arctic's shrinking sea-ice cover, Science, 315, 1533-1536, doi:10.1126/science.1139426, 2007.

Shindell, D. and Faluvegi, G.: Climate response to regional radiative forcing during the twentieth century, Nat. Geosci., 2, 294300, 2009.

Shupe, M. D.: Clouds at Arctic Atmospheric Observatories. Part II: Thermodynamic Phase Characteristics, J. Appl. Meteor. Climatol., 50, 645-661, doi:10.1175/2010JAMC2468.1, 2011.

Skeie, R. B., Berntsen, T., Myhre, G., Pedersen, C. A., Ström, J., Gerland, S., and Ogren, J. A.: Black carbon in the atmosphere and snow, from pre-industrial times until present, Atmos. Chem. Phys., 11, 6809-6836, doi:10.5194/acp-11-6809-2011, 2011.

Søvde, O. A., Gauss, M., Smyshlyaev, S. P., and Isaksen, I. S. A.: Evaluation of the chemical transport model Oslo CTM2 with focus on arctic winter ozone depletion, J. Geophys. Res, 113, D09304, doi:10.1029/2007JD009240, 2008.

Stamnes, K., Tsay, S., Wiscombe, W., and Jayaweera, K.: Numerically stable algorithm for discrete-ordinate-method radiative transfer in multiple scattering and emitting layered media, Appl. Optics, 27, 2502-2509, 1988.

Stroeve, J., Serreze, M. C., Holland, M. M., Kay, J. E., Malanik, J., and Barrett, A. P.: The Arcti's rapidly shrinking sea ice cover: A research synthesis, Climatic Change, 110, 1005-1027, doi:10.1007/s10584-011-0101-1, 2011.

Wild, O., Prather, M., and Akimoto, H.: Indirect long-term global radiative cooling from $\mathrm{NO}_{\mathrm{x}}$ emissions, Geophys. Res. Lett., 28, 1719-1722, 2001. 